\title{
Um Leque de Possibilidades: Materiais
}

O artista [...] se pinta, escreve ou se faz filmes é porque viu quadros, leu romances ou assistiu a filmes.

(Robert Stam)

Stava na hora de começar. O grande propósito: criar um espetáculo
unipessoal que partisse da solidão na sala de ensaio e prescindisse de um olhar externo que escolhesse e dirigisse a proposta cênica. Os pressupostos estavam ali para me guiar por um caminho que só eu mesmo poderia construir. No entanto, a pergunta principal era qual seria o meu ponto de partida. Encontrei a resposta nas palavras de Odete Aslan (1979), citadas no primeiro capítulo, quando define a noção de ator-criador a partir da nostalgia daquele que não pode criar um objeto artístico concreto (como o escritor, o pintor ou o compositor). Resistente àquela ideia mais tradicional do ator que não pode por si mesmo ser o criador de sua obra, a chave deveria se encontrar nos meios que usam aqueles outros artistas.

Fala-se habitualmente que, se o poeta conta com a palavra para criar sua obra ou o pintor com as tintas, o ator tem para seu ato criativo a ação física. Na formação dos atores, essa é uma premissa básica. Sobre isso, o encenador e o educador argentino Jorge Eines assinala (1997a):

[a] Técnica das Ações Físicas Fundamentais está presente em toda tentativa pedagógica ou de encenação, seja pela sua aplicação, pela omissão ou pela comparação com outras técnicas e, sobretudo, sua 
presença se deve àquilo que a ação tem de indissolúvel à tarefa do ator. (p. 21, tradução minha, maiúsculas no original)

Aquela indissolubilidade faz da ação física a matéria por excelência do ator. No mesmo sentido, o pesquisador brasileiro Matteo Bonfitto (2009) nomeia a ação física como elemento estruturante do fenômeno teatral. Para corroborar essa afirmação, sua pesquisa sobre o tema faz um percurso que rastreia o conceito de ação física desde Stanislávski até Barba.

Para ambos os autores —Eines e Bonfitto-, a ação física constitui o eixo do trabalho do ator. Além disso, eles partem de Stanislávski para suas respectivas conceptualizações. O primeiro fala em Técnica de Ações Fundamentais ao se referir à sistematização da obra do encenador russo. Por sua vez, o segundo afirma que "o conceito de ação física foi primeiramente elaborado por Constantin Stanislávski (18631938), após inúmeras etapas de aprendizado e prática teatral” (Bonfitto, 2009, p. 21, itálico no original).

Isso que conecta o trabalho dos dois pesquisadores será o ponto de partida deste capítulo assim como foi o ponto de partida do processo criativo aqui discutido. Colocando-me como ator emancipado que, a partir da solidão, criaria um espetáculo teatral, aquilo que minha formação tinha me dado seria a matéria que me forneceria ferramentas para iniciar. Isso não é nada mais do que a ação física.

Nas minhas experiências teatrais anteriores, inclusive a de $L a$ navidad de Harry, a ação física tinha me dado os recursos suficientes para desenvolver meu trabalho como ator. Jorge Eines foi o autor que sistematizou a técnica que me ensinaram e que constitui a coluna vertebral da minha formação ${ }^{1}$. O conceito de ação física de Eines não dista muito do de Stanislávski e, da mesma forma que o diretor

1 Foi com Carlos Bolívar, discípulo de Eines na Escuela de Arte Dramático de Madrid (Resad, Espanha), que iniciei minha formação acadêmica na Universidad de Antioquia (Colômbia). Posteriormente, Bolívar foi meu diretor em várias das montagens do grupo Íntimo Teatro. Seu método de trabalho se baseia na técnica de Eines, a qual define o trabalho do ator a partir da interpretação do texto dramático e considera a ação física como um elemento transformador da cena. Atualmente, Carlos Bolívar é professor da Escola de Jorge Eines, Ensayo 100, de Madri. 
russo, parte do texto para a construção das ações físicas. No entanto, eu não partiria de um texto dramatúrgico para a experimentação criativa, dado que o interesse da pesquisa é criar um espetáculo que desconsidere a ideia mais tradicional de que o autor da obra teatral é necessariamente o dramaturgo. Além disso, procura-se um exercício criativo que ignore a perspectiva textocêntrica do acontecimento cênico. Seria, nessa ordem de ideias, a ação física o material suficiente para abordar meus propósitos?

$\mathrm{Na}$ pergunta anterior, aparece uma palavra que define as particularidades deste capítulo: material. Entendo por material esses meios que estaria buscando, homólogos aos dos outros artistas, para a criação da minha obra como ator. Para definir essa questão, Bonfitto pode ser esclarecedor. Na busca do que ele define como ator compositor, o pesquisador brasileiro incursiona no conceito de material. Partindo, por sua vez, do conceito aristotélico de matéria, conclui que "[...] por material pode-se entender qualquer elemento que adquire uma função no processo de construção da identidade do próprio objeto" (Bonfitto, 2009 , p. 17, itálico no original). Assinala, também, que o termo foi usado por vários diretores teatrais (Meierhold, Brecht, Barba e Kantor), embora tenha sido utilizado em diferentes sentidos por cada um deles (Bonfitto, 2009, p. 17).

Baseado na definição que ele mesmo conclui e nas contribuições de autores como François Delsarte, Jacques Dalcroze e dos teatros orientais, Bonfitto faz uma classificação dos materiais do ator assim: o corpo (material primário), as ações físicas (secundário) e os elementos constitutivos das ações físicas (terciários). Definidas essas três categorias, a única que parece receber um estudo aprofundado é a que classifica como secundária: a ação física. $O$ corpo parece ser o material primário só pelo fato de conter os outros dois, enquanto os terciários preenchem e justificam a ação. A ação física, assim, é definida como o elemento estruturante dos procedimentos expressivos do corpo (Bonfitto, 2009). Em conclusão, o material por excelência do ator não é nada mais do que a ação.

Levando essa consideração até as últimas consequências, Bonfitto (2009) levanta a hipótese da “[...] ação física como elemento estruturante do fenômeno teatral, sobretudo daquele que confere ao ator 
o valor de eixo de significações" (p. 138). Essa conclusão é possível para o pesquisador depois de estabelecer algumas relações entre a ação física e outros elementos do espetáculo, como o espaço, o figurino, os objetos, a luz, a música e a palavra. Tudo isso para um teatro que considera o ator o eixo da obra, mas que não oferece para ele nenhum outro tipo de participação além de sua função interpretativa. Assim, a ação física se constitui como o material do ofício do ator. Mas, como ficou claro no primeiro capítulo, se me encontro saindo do plano do ofício para entrar no plano da arte, os materiais têm que ser outros além deste.

Como pensar, então, o conceito de material para uma prática criativa na qual o ator vai ter que fornecer também esses outros elementos ao espetáculo? Se o material por excelência do trabalho do ator como intérprete é a ação física, quais serão os materiais de que precisará um exercício de criação autônoma no qual o ator é o responsável pelo tecido total da obra? Para responder a essas novas questões, volto ao assunto que fechou a primeiro capítulo: a necessidade de falar com nome próprio.

Tendo como objetivo a ideia de ator-autor a partir das potencialidades do espetáculo unipessoal e o desejo de assinar a própria obra, os materiais que buscava não podiam estar em outro lugar que não fosse em mim mesmo. Se meu desejo é levar ao palco minha visão do mundo e privilegiar meu dizer, onde encontrar isso? Já Luigi Pareyson (1997) tinha me dado luzes nesse sentido quando assinala que o mundo do artista se materializa na sua personalidade concreta, na sua espiritualidade. Teria que procurar, então, as fontes dessa minha espiritualidade. A noção de imaginário me ajudou a esclarecer esse lugar.

\section{Acervo e imaginário}

Quando falo em acervo, estou me referindo àquele conjunto de referências que fazem parte do que eu sou. Em geral, a palavra é usada para definir "[o] conjunto das obras que integram o patrimônio duma biblioteca, dum museu, etc.” (Ferreira, 2010, p. 10). Esse patrimônio 
pode ser do âmbito artístico, bibliográfico, científico, documental, genético, iconográfico, histórico, entre outros. Além disso, pode pertencer a um indivíduo em particular, a uma instituição ou a uma nação. De fato, a palavra é proveniente do termo latino acervus, que significa coleção. Para encontrar meu dizer como artista, começo por examinar meu acervo pessoal, minha própria coleção de referências, e tirar dela aquilo que vai me servir para a construção da obra.

Ítalo Calvino apresenta um argumento que é fundamental para entender o caminho que empreendi na busca do meu acervo:

[...] quem somos nós, quem é cada um de nós senão uma combinatória de experiências, de informações, de leituras, de imaginações? Cada vida é uma enciclopédia, uma biblioteca, um inventário de objetos, uma amostragem de estilos, onde tudo pode ser continuamente remexido e reordenado de todas as maneiras possíveis. (Calvino, 1990, p. 138)

Coleção, inventário, patrimônio, amostragem ou conjunto de experiências e de bens, no caso do artista, cada um tem uma série de referências à qual acessa quando enfrenta o ato criativo. Desse patrimônio, vão sair os materiais que darão identidade à minha obra.

Se o acervo de uma instituição se encontra dentro de um edifício (biblioteca, museu, entre outros), onde procurar o pessoal? O conceito de imaginário responde a essa questão. Juremir Machado Silva define a noção a partir de uma palavra que se une à de coleção e à de patrimônio: reservatório.

O imaginário é um reservatório/motor. Reservatório, agrega imagens sentimentos, lembranças, experiências, visões do real que realizam o imaginado, leituras de vida e, através de um mecanismo individual/grupal, sedimenta um modo de ver, de ser, de agir, de sentir e de aspirar ao estar no mundo. O imaginário é uma distorção involuntária do vivido que se cristaliza como marca individual ou grupal. Diferente do imaginado - projeção irreal que poderá se tornar real —, o imaginário emana do real, estrutura-se como ideal e retorna ao real como elemento propulsor. (Silva, 2003, p. 11-12) 
A definição anterior se conecta claramente com aquilo que estou chamando de acervo pessoal. Aliás, amplia esse conceito no fato de contemplar também noções como sentimentos, lembranças, visões do real e leituras da vida. Entende-se, por um lado, o imaginário como lugar de depósito de experiências e, por outro, como um dispositivo móvel. Assim, palavras como propulsor, motor e mecanismo permitem que a percepção do conceito carregue a ideia de movimento. O imaginário é, dessa maneira, uma experiência viva em constante transformação, o que possibilita uma mutação da realidade. Na hora da criação, esse reservatório constitui um leque de possibilidades que partem da realidade, mas que se caracterizam como estímulos produto daquela distorção involuntária. Para o caso individual, imaginário e acervo pessoal podem se integrar em uma expressão que considero sintética dessa relação: mundo interior. No entanto, Silva é claro ao afirmar que esse estar no mundo é uma condição que particulariza a realidade tanto no caso do indivíduo quanto no da experiência de grupo.

A construção do imaginário individual se dá, essencialmente, por identificação (reconhecimento de si no outro), apropriação (desejo de ter o outro em si) e distorção (reelaboração do outro para si). O imaginário social estrutura-se principalmente por contágio: aceitação do modelo do outro (lógica tribal), disseminação (igualdade na diferença) e imitação (distinção de todo por difusão de uma parte). (Silva, 2003, p. 13)

Assim, o imaginário, enquanto apropriação da realidade, acaba se convertendo em uma reformulação dela que pode determinar as formas como uma sociedade ou uma pessoa vê, sente ou age no mundo. Em contraste, Michel Maffesoli (2001) argumenta, em uma entrevista publicada pela revista Famecos, que "[o] imaginário é o estado de espírito de um grupo, de um país, de um Estado-nação, de uma comunidade, etc. O imaginário estabelece vínculo. É cimento social. Logo, se o imaginário liga, une numa mesma atmosfera, não pode ser individual" (p. 76). Essa afirmação parece, à primeira vista, contrária à de Juremir Machado Silva, mas realmente os dois autores estão falando sobre a mesma questão. Ambos consideram o imaginário como produto da sua inerente condição 
social. Quando penso no imaginário “pessoal”, não estou fazendo referência a uma ideia de autonomia e independência absoluta.

De fato, embora Silva dedique várias páginas de seu estudo à definição do imaginário individual, como se mostrará daqui a pouco, acredito que o entende mais como uma apropriação individual do imaginário, que é, na origem, uma experiência coletiva. Por isso, quando apresenta as três possibilidades de construção do imaginário individual, ressalta precisamente sua condição social. Por meio do reconhecimento do outro, do desejo de se apropriar dele ou da reelaboração do proposto pelo outro, nosso imaginário acaba sendo só distorção ou adaptação da experiência social. Nesse sentido, o imaginário social se constrói por contágio. Nessa citação, embora o autor esteja separando os procedimentos de construção do imaginário individual e do imaginário social, evidencia-se que ambos estão operando na mesma lógica. Os modelos de aceitação, imitação e disseminação podem perfeitamente explicar tanto um como o outro.

Voltando à experiência individual, o imaginário é esse lugar no qual se concentra minha apropriação do mundo e se reúnem as diferentes visões sociais que me atravessam. Para o propósito da criação do meu espetáculo unipessoal, teria que pensar como meu imaginário poderia contribuir com a aparição dos materiais que precisava para a construção da identidade de minha obra (lembrando a definição de material de Bonfitto).

A necessidade de falar com nome próprio já tinha me dado um tema, pelo menos no sentido geral, do qual eu queria falar em cena: a homossexualidade. Interessava-me, particularmente, a dupla moral da sociedade atual que aparentemente aceita a condição do homossexual, desde que não seja expressa abertamente. Meu dizer estava diretamente relacionado com o fato de apresentar a homossexualidade como uma realidade latente e fora das sombras.

Essa relação entre "realidade latente" e "sombras" tem muito a ver com as estruturas de ocultação e revelação que envolvem constantemente as narrativas sobre a homossexualidade. Assim o assevera Eve Kosofsky Sedgwick (2003) na sua Epistemologia do armário: 
[e]ntendo que uma boa parte da energia e da atenção dispendidas em assuntos relacionados com a homossexualidade [...] foi sustentada pela relação claramente indiciadora entre homossexualidade e estruturas mais vastas de ocultação e de revelação, do que é público e do que é privado. (p. 11)

Como artista, enfrentava, então, o desafio de levar ao palco um dizer próprio sobre uma situação que, claramente, atingia a uma experiência coletiva, mas que partia de interesses pessoais. Por esse motivo, inicialmente, pensava que a minha experiência pessoal seria suficiente para afrontar essa empresa. Como indivíduo abertamente gay, sentia-me na capacidade de levar essa abertura ao palco. Contudo, quando comecei a enfrentar o exercício criativo, rapidamente percebi que o que estava dentro de mim nada mais era do que uma aproximação particular de realidades e de experiências que me atravessavam e que vinham do imaginário coletivo. Minha ideia da homossexualidade não era só produto da minha orientação sexual —o que no começo parecia-me uma obviedade-; era, finalmente, meu imaginário individual sobre o que é ser homossexual.

Nesse ponto, a palavra acervo e a palavra imaginário já não me pareciam tão próximas porque o imaginário acabou sendo esse edifício que estava procurando dentro de mim, minha biblioteca pessoal, meu museu de experiências. O acervo está dado por todos os materiais que estão contidos nesse meu prédio interior. Novamente, Maffesoli apareceu para me esclarecer o assunto. $\mathrm{Na}$ mesma entrevista já citada, o sociólogo francês menciona o conceito de tecnologias do imaginário. Por elas, entende todo aquele desenvolvimento tecnológico que contribui na formação desse grande reservatório que é o imaginário. Assim, assevera:

[o] imaginário é alimentado por tecnologias. A técnica é um fator de estimulação imaginal. Não é por acaso que o termo imaginário encontra tanta repercussão neste momento histórico de intenso desenvolvimento tecnológico, ainda mais nas tecnologias de comunicação, pois o imaginário, enquanto comunhão, é sempre comunicação. (Maffesoli, 2001, p. 80) 
Esta última afirmação citada aparece em um contexto no qual Maffesoli está tentando explicar o imaginário pós-moderno a partir de sua visão do tribalismo atual. Para atingir seu propósito, encontra nas mídias uma explicação para a disseminação que comporta as práticas sociais dos últimos tempos. A televisão e a internet, por exemplo, constituem elementos fundamentais para entender a construção desse imaginário. É importante entender que o autor não está se referindo exclusivamente a novas mídias ${ }^{2}$, já que o imaginário sempre foi alimentado por tecnologias (velhas ou não).

A escrita, só por citar um exemplo, é uma das tecnologias mais revolucionárias de todos os tempos. No meu caso, a literatura é uma das primeiras tecnologias de comunicação que alimentou meu imaginário. Como bem assinala Maffesoli, essas tecnologias são as que estimulam nossa lógica imaginal. Assim, além da minha experiência viva, a imagem que tenho da homossexualidade está dada pelas minhas leituras sobre o tema, pela iconografia que a define no mundo que me correspondeu, pelas teorias científicas que a descrevem, pela história em si da condição e do contexto social que a envolve, enfim, por todas as informações que recebo e recebi relacionadas com ela, pela minha apropriação individual do imaginário coletivo sobre a

2 Em tempos nos quais todo mundo fala em novas mídias, é importante especificar à qual nos estamos referindo quando usamos essa expressão. Para garantir a clareza do exposto, Lev Manovich (2003) oferece um panorama concreto sobre o que seriam essas novas mídias. Um dos primeiros esclarecimentos que apresenta se refere a que as novas mídias não devem se confundir só com as tecnologias de comunicação em rede, mas também incluir todos os objetos e os paradigmas culturais capacitados por todas as formas de computação. Essas formas de computação, no entanto, obedecem a critérios que constantemente se renovam — os princípios de modularidade, variabilidade, automação e transcodificação definem as características mais contemporâneas das mídias controladas por software-, o que demanda que os produtos culturais que conformam a categoria de novas mídias sejam também renovados, assim como a sua própria definição. Dessa maneira, poderiam se definir as novas mídias como: "[c]aracterísticas estéticas específicas que continuam a reaparecer em uma etapa inicial de posicionamento de todas as novas tecnologias das mídias modernas e da telecomunicação" (Manovich, 2003, p. 37). 
condição dos homossexuais. Eis, então, a grande estante onde deveria procurar meus materiais.

Esse tipo de apropriação pessoal está muito bem apresentada na fala de Juremir Machado Silva, sobretudo porque a aproveita para dar mais uma definição de imaginário.

O imaginário surge da relação entre memória, aprendizado, história pessoal e inserção no mundo dos outros. Nesse sentido, o imaginário é sempre uma biografia, uma história de vida. Logo, é menos redutor do que a ideologia, mais aberto do que a crença e menos completo do que a cultura, na qual se insere e a qual alimenta. (Silva, 2003, p. 57)

Sendo sempre uma biografia, consequentemente será experiência pessoal. Isso apoiou minha intuição inicial de que dentro de mim estariam os materiais que precisaria para a construção de identidade do meu ato criativo.

Graças às palavras de Machado Silva, entendi que, sendo o imaginário mais próximo da biografia, o que faria no meu processo criativo seria reforçar aquela ideia de tratar o tema do ponto de vista artístico, oferecer mais uma versão, coletivizar minha singularidade através do palco. A metáfora do imaginário como biografia permite diversificar esse conceito porque, na história de vida, cabe perfeitamente o racional, o onírico, o lúdico, o afetivo, o irracional, o imaginativo e o emotivo, entre muitas outras possibilidades. De alguma maneira, esse universo me permitiu entender que o imaterial para o artista é sempre suscetível de se transformar em material da criação, e que minha busca encontrava finalmente uma fonte de exploração de possibilidades. Talvez seja por esse tipo de conexões que o imaginário acaba sendo definido por Maffesoli como aquela aura que ultrapassa e alimenta a cultura. Para atingir meu objetivo e explorar a riqueza dos materiais que meu imaginário me forneceria, só teria que me afastar das hermenêuticas redutoras ${ }^{3}$.

3 Por hermenêuticas redutoras, Gilbert Durand entende aquelas doutrinas que “[...] só descobrem a imaginação simbólica para tentar integrá-la na sistemática intelectualista estabelecida, apenas para tentar reduzir a simbolização a um simbolizado sem mistério" (1998, p. 41). Como exemplo dessas 
Dessa maneira, ficou definido que devia acudir ao meu imaginário para encontrar aquele acervo que procurava. Esse acervo está composto por inúmeros materiais provenientes da minha apropriação do real. Como encontrar os materiais adequados? Como em uma biblioteca, devia transitar por diferentes corredores, procurar nos mais remotos becos desse imaginário e revisar cuidadosamente o meu índice de experiências. Para determinar esses materiais, devia levar em conta o conceito de tecnologias do imaginário, aquelas que formaram minha imagem da homossexualidade que pretendia levar à cena.

Essa indagação me levou a escolher vários materiais. Uns deles apareceram no primeiro momento da busca, outros chegaram depois de iniciada a etapa de ensaios, alguns apareceram no final do processo criativo. Independentemente do momento de chegada, neste capítulo, esses materiais estão catalogados em relação com as tecnologias que os contêm. Serão descritos na seguinte ordem: leituras, iconografia e experiência biográfica.

\section{André Gide e o discurso imoralista}

Definido o que entendo por acervo a partir da noção de imaginário, posso afirmar que minhas leituras são peça fundamental do meu patrimônio, da minha coletânea de experiências. Pensando quais seriam aquelas leituras que nutriram meu imaginário sobre a homossexualidade, encontrei vários autores, entre eles Marguerite Yourcenar, Fernando Vallejo e André Gide. Isso não quer dizer que foram os únicos que alimentaram em mim essa ideia, mas sim os que mais marcaram a minha vida até o momento de começar a criação do espetáculo unipessoal.

doutrinas, Durand coloca, entre outros, a psicanálise e a psicologia social. Por oposição, fala das hermenêuticas instauradoras. Seu exemplo mais revelador é a fenomenologia do imaginário de Bachelard, sua "escola da ingenuidade" (Durand, 1998, p. 67). O primeiro capítulo deste livro demonstra a concordância concordância desta pesquisa com as impressões de Durand. 
Alexis ou o tratado do vão combate (1929) e Memórias de Adriano (1951) de Marguerite Yourcenar foram romances que deixaram em mim uma forte impressão, especialmente o primeiro. De fato, a primeira ideia de levar ao palco uma temática dessa índole surgiu depois de concluir a leitura de Alexis. Trata-se de um romance epistolar no qual o protagonista decide confessar sua homossexualidade para sua esposa. $\mathrm{O}$ vão combate, precisamente, descreve a luta de um homem por apagar seus instintos e negar a paixão que o define como ser humano. $\mathrm{Na}$ carta, ele se despede de sua mulher e se desculpa, como se vê a seguir.

Sem saber viver segundo a moral ordinária, trato, pelo menos, de concordar com a minha. É no momento no qual a gente rejeita todos os princípios quando convém se fornecer de escrúpulos. Tinha contraído contigo compromissos imprudentes e a vida se encarregou de protestar: peço-te perdão, o mais humildemente possível, não por te deixar, mas por ter ficado tanto tempo. (Yourcenar, 2002, p. 165 , tradução minha)

Esse conflito entre a moral ordinária e a fidelidade à natureza própria foi, talvez, o que mais reverberou em mim depois de Alexis. Também me levou à busca de novas referências ao redor do tema, o que acabou me aproximando de André Gide.

O segundo autor que é definitivo na consolidação do meu imaginário sobre a homossexualidade é Fernando Vallejo. Esse autor colombiano me deu um olhar muito próximo sobre a realidade do homossexual no meu país. Suas obras retratam situações e experiências que acontecem na minha cidade. Seus personagens têm a cara da minha gente e falam com as gírias da minha região, embora Vallejo seja um mestre da gramática espanhola e, em muitos dos seus romances, denuncie a proximidade entre a degradação da sociedade e a da língua.

Se Yourcenar fala em "vão combate" para se referir à homossexualidade, Vallejo usa a expressão "fogo secreto" com o mesmo propósito. De fato, assim intitula seu romance El fuego secreto (1986), o primeiro que desenvolve mais abertamente um tópico que permanece no restante da obra literária do autor colombiano: a 
homossexualidade do protagonista-narrador (Jurado-Valencia, 2013). María Mercedes Jaramillo (2013), uma das críticas literárias mais reconhecidas da Colômbia, afirma que, na literatura desse país:

[a]través das obras de Vallejo começa a visibilidade do mundo clandestino dos homossexuais, seus interesses e suas formas de vida, as quais têm sido silenciadas e satanizadas pela sociedade patriarcal, que em sua dupla moral permite e aceita os bordéis e o tráfico de mulheres, mas tolera as campanhas de limpeza social que têm tido como um dos seus alvos os travestis e os homossexuais que têm que se sustentar do comércio sexual. (p. 76, tradução minha)

Fogo secreto ou vão combate, a homossexualidade para esses dois autores representa um estado interior que relativiza a moral pública. $\mathrm{Na}$ definição do meu imaginário sobre a homossexualidade, a contribuição desses dois literatos é fundamental e acabou me levando à leitura de André Gide, que diretamente faz parte do ponto de partida para a construção do meu espetáculo unipessoal. Cheguei ao autor por uma série de recomendações que veio da leitura do Alexis, de Yourcenar. No começo, aproximei-me a partir da leitura do romance O imoralista (1902), obra que deu ao escritor grande reconhecimento. Depois, Corydon (1920) e O pombo torcaz, conto breve escrito aproximadamente em 1907 e publicado post-mortem.

André Paul Guillaume Gide nasceu em Paris no dia 22 de novembro de 1869 e morreu na mesma cidade no dia 19 de fevereiro de 1951. Recebeu o Prêmio Nobel de Literatura em 1947. É um dos escritores mais lembrados pela sua assumida homossexualidade e seu discurso abertamente a favor dos gays. Esse fator, unido à sua denúncia do colonialismo, fizeram com que sua obra fosse objeto de rejeição de vários setores. Em 1952, por exemplo, sua obra foi incluída no Index de livros proibidos pelo Vaticano.

Gide foi um autor fértil e multifacetado, que cultivou não só a ficção mas também a crônica, a crítica literária, o ensaio, o gênero epistolar (destinado, como foi demonstrado, finalmente ao grande público), o diário pessoal e outras formas de escrita. Em todos 
esses gêneros, seu estilo claro, elegante e ilustrado, suscita constantemente a admiração dos seus leitores e, sem dúvida, o fato cumpriu um papel nos reconhecimentos que recebeu [...] Foi louvado com veneração e vituperado com extrema severidade pelas suas posições, com certeza, corajosas e visionárias; pelas suas críticas às infâmias cometidas sob o colonialismo francês na África; pela sua defesa da legitimidade da homossexualidade como forma de existência; pelos seus questionamentos à União Soviética, apesar da sua proximidade aos meios comunistas, e por outros fatos que assumiu como causas próprias. Nesse sentido, é importante destacar que suas obras eram tanto fenômenos literários quanto motivos de escândalo. (Pérez, 2011, p. 33-34, tradução minha)

Sobre o mérito de Gide, Juan Fernando Pérez (2011) diz que se trata de um escritor muito relevante, especialmente a partir da primeira ou segunda década do século passado, momento no qual Gide começa a ocupar um lugar de honra na literatura francesa. Por isso, foi objeto de todo tipo de referências, de estudos e de biografias, o que coincidiu com o recebimento do Nobel. Foi considerado, sem vacilações, um farol da literatura universal.

O imoralista, meu primeiro contato com a obra de Gide, conta a história de Michel, um homem que, após se recuperar de uma grave tuberculose, reconfigura sua vida e assume uma nova forma de se relacionar com o mundo por meio da aceitação de sua homossexualidade. Esse assunto, no entanto, aparece na obra a partir de alusões delicadas e indiretas, que são subentendidas pelo leitor a partir das situações descritas, como sua preferência por passar o tempo com os trabalhadores rurais das suas terras e sua atração pelos jovens adolescentes que encontra nas suas viagens.

É que os meus trabalhos e os meus gostos já não eram mais os do ano anterior. Minhas terras, devo confessar, não me interessavam tanto quanto os homens que nelas trabalhavam; e, para frequentá-los, a presença de Carlos seria embaraçosa. O rapaz era demasiado sensato e gostava de fazer-se respeitar. Daí que, apesar da viva emoção que a 
sua lembrança despertava em mim, eu visse com receio aproximar-se o dia do seu regresso. (Gide, 1972, p. 91)

Durante esses tristes dias, os meninos foram a minha única distração. Quando chovia, só os mais íntimos entravam; tinham as roupas molhadas; sentavam-se, em círculos, ao pé do fogo. Eu me sentia demasiado cansado e enfermo para fazer outra coisa senão olhá-los; mas a presença de sua saúde me curava. [...]

Uma manhã, tive uma revelação curiosa de mim mesmo: Moktir, o único protegido da minha mulher que não me irritava (talvez por ser bonito), ficara só comigo no meu quarto; até então, não me atraia muito, mas seu olhar brilhante e sombrio me intrigava. [...] (Gide, 1972, p. 33)

A crítica da época relacionou Gide com sua personagem Michel, sobre o que ele manifestou que se tratava apenas de uma virtualização da sua personalidade. No entanto, o uso da primeira pessoa na escrita desse romance, recurso recorrente em toda sua obra, deixa entrever uma intenção confessional que comove profundamente. Sobre isso, JacquesAlain Miller (2000-2001, p. 36) afirma que a criação literária de Gide está muito marcada pelo Je (o autor prefere usar a palavra francesa por considerá-la mais exata). Existe nesse Je, segundo o crítico, uma grande fatalidade, o que dá bastante peso à obra. Assim, Miller assinala que as peças que conformam o conjunto de escritos de Gide têm, na sua maioria, o caráter de uma narração egológica contínua.

Esse traço resulta fundamental para entender como a obra de Gide causou grande impressão no meu imaginário da homossexualidade. De fato, os três autores que mencionei como determinantes nas minhas leituras sobre o tema fazem uso desse recurso narrativo. Voltarei ao assunto do eu narrativo quando falar da experiência autobiográfica.

Por enquanto, o que deixou uma marca mais profunda na minha experiência como leitor foi isso que intitulei aqui como seu discurso imoralista. A história narrada por Michel deixa entrever uma série de vivências que contrariam os costumes da sociedade guiada pelas normas da heterossexualidade. Assim, Michel apresenta um discurso 
que não se refere a uma visão moral das novas experiências. A homossexualidade, embora sutil, é narrada sem nenhum tipo de juízo moral. Da mesma forma, é descrita a experiência extraconjugal. O Gide de O imoralista é o mesmo que afirmou no Tratado do Narciso que "[v]ivemos para manifestar. As regras da moral e da estética são as mesmas: toda obra que não manifesta é inútil e, por isso, medíocre. Todo homem que não manifesta é inútil e medíocre" (citado por Montoya-Campuzano, 1999, p. 23, tradução minha). Em consonância com essas afirmações e com a crítica da moral, a personagem Michel dirá, em algum momento do romance, o seguinte: "[d]etesto os homens de princípios" (Gide, 1972, p. 79).

Nessa ordem de ideias, aparece na obra de Gide uma contradição entre o desejo e as normas sociais. A personagem Michel passa do casamento com uma mulher, fato influenciado pela satisfação do pai, ao reconhecimento do fogo interior. A busca de si mesmo, para Gide, é representada no encontro do desejo erótico. Sobre esse assunto, Blas Matamoro (2001) afirma que ser si mesmo para Gide sempre foi uma ousadia, mas não por imitação ou por contradição nem pela intenção deliberada de ser ousado, mas sim como dever ser, como se esse si mesmo pudesse ser algo puro e indeterminado. Talvez essa direção seja a que leva ao crítico Ciro E. Schimidt Andrade (2001b) a afirmar que $O$ imoralista exalta, em nome do desejo, a liberação da moral e da religião.

À frente da moral e da religião, Gide coloca o desejo. Cristina Marqués Rodilla (2000) diz que o desejo de Gide é o do nome próprio, o desejo de um designador rígido que expresse sua originalidade e sua pessoal diferença ante o tribunal da história. Além disso, assinala que o autor francês é um homem de verdade porque não renuncia ao seu desejo. Embora essas afirmações partam dessa hermenêutica redutora que é a psicanálise 4 , o tema do desejo esclarece o que podemos

4 Fala-se muito de André Gide a partir da perspectiva da psicanálise. Vários dos críticos citados neste capítulo — entre eles, Marqués e Miller- partem dos estudos de Lacan sobre sua obra. No entanto, em concordância com Durand, a suposta "homossexualidade masturbatória", seu complexo edípico, sua pedofilia, seu casamento "branco" e seu onanismo, entre outras tantas "aberrações” 
considerar o imoralismo de Gide. A respeito, cito um fragmento da fala de Michel no romance.

E cada dia aumentava em mim o sentimento confuso de riquezas intatas, que cobriam, escondiam, abafavam as culturas, as decências, as morais.

Parecia-me então que eu nascera para um gênero, desconhecido de descobertas; e entregava-me apaixonadamente àquela pesquisa tenebrosa, para a qual o pesquisador deve adjurar e afastar de si a cultura, a decência e a moral.

Daí eu só admitir nos outros as manifestações mais selvagens, e deplorar qualquer refreamento que os pudesse reprimir. Por pouco, só veria na honestidade restrições, convenções ou temor. Teria gostado de aceitá-la como uma dificuldade rara; nossos costumes tinham feito dela a forma mútua e banal de um contrato. (Gide, 1972, p. 108)

O desejo, pois, reprimido pelos costumes e pelas convenções de uma sociedade "honesta". A sinceridade para Gide estaria mais próxima daquelas riquezas inatas apagadas pelas morais. A descoberta do prazer acaba sendo, a partir da perspectiva de $O$ imoralista, uma busca tenebrosa que estimula a não repressão do desejo. Em oposição, encontram-se as convenções, as restrições e o temor que defendem as sociedades decentes. "Eu me agito neste dilema: ser moral, ser sincero" (Gide citado por Schimidt-Andrade, 2001b, p. 191, tradução minha).

Sobre a questão da verdade, Matamoro (2001) diz que Gide proclama uma estética da sinceridade. Segundo o crítico, o desejo em

evidenciadas pelos fãs de Lacan, gozam de pouquíssima importância nesta pesquisa. De fato, Marqués (2000) assevera que Gide reúne todos os tópicos requeridos pela psicanálise. Além disso, no seu próprio artigo, a pesquisadora afirma que, em conversas com seu biógrafo Delay, Gide declarou que, de ter existido a terapia psicanalítica na sua infância e de ter sido submetido a ela, as consequências para ele teriam sido irreparáveis, dado que considerava que a catarse do artista só se realiza por meio da própria obra (Marqués, 2000). Não posso concordar melhor com Gide. 
Gide é alimentado pela utopia de que existe um ser humano natural, amoral e sincero, oposto à insinceridade do ser humano moral e fictício. Nessa busca, o Michel do romance afirma: "tenho horror às pessoas honestas" (Gide, 1972, p. 109). Mais adiante, critica a "honestidade dos povos”. Sobre os suíços, por exemplo, dirá: “[h]onesto povo suíço! De nada lhe vale comportar-se bem... sem crimes, sem história, sem literatura, sem artes... um grande roseiral sem espinhos nem flores...” (Gide, 1972, p. 109).

Contrariamente ao que se entende como tautologia, um país como a Suíça, reconhecido como sociedade civilizada por excelência, acaba sendo pouco interessante conforme a perspectiva gideana. Não existe para Michel (nem para Gide), então, nada que dê valor a uma sociedade que se diz honesta: sem crime, não há possibilidade de arte. Assim, a verdadeira moral defendida em $O$ imoralista seria uma muito relacionada como a ética e a estética, assunto fundamental para entender os alcances da obra do escritor francês.

Toda desordem é contrária à harmonia e, pela mesma razão, à beleza. Por isso, o pecado para ele consiste em uma ruptura dessa beleza e num atentado contra sua própria sensibilidade, o que faz com que toda norma de bem esteja referida à própria sensibilidade e seja basicamente apropriada a partir da experiência estética: "Fazer com que habite a ideia de perfeição, do desejo, não no equilíbrio e na medida, mas no extremo ou na superabundância, é talvez o que definirá melhor nossa época" (Journal I 310). (Schimidt-Andrade, 2001a, p. 111, tradução minha)

Nesta última citação, fica claro o que definiria a moral de Gide. A ausência de ordem será, pois, um ataque à beleza. O pecado não é, então, um atentado contra a convenção. Todo o contrário, será uma ofensa ao impulso natural, ao desejo, que, em último caso, se traduz como busca da beleza. Assim, para Gide, a beleza se faz normatividade da existência (Schimidt-Andrade, 2001a, p. 112) e a escrita uma expressão da sua singular forma de perceber o estético (Schimidt-Andrade, 2001a, p. 110). 
O trabalho artístico [para Gide] parte da liberdade para renunciar a ela, quando se identifica o verdadeiro desejo e submete-se a ele. E esse é também um ato moral, platonicamente precedido pela intuição do belo. A beleza é o chamariz da bondade. Daí que a arte não seja moral pelos seus pressupostos, que não deva se submeter a um código moral, embora seja moral pelos seus efeitos, como toda ação humana. (Matamoro, 2001, p. 119, tradução minha)

Assim como a beleza, a sabedoria estaria dada por oposição às convenções. No seu Journal, André Gide afirma que o ser humano sábio vive sem moral, conforme a sua própria prudência, e convida o leitor a tentar alcançar o que ele chama de "imoralidade superior" (citado por Matamoro, 2001, p. 115). O que seria essa imoralidade? Matamoro (2001) assinala que, se fosse necessário sintetizar a moral gideana, poderia se dizer que se trata de uma ética da disponibilidade, de uma antropologia do indivíduo disponível. Isso faz referência a uma "apaixonada indecisão", com algum grau de indiferença, pelos contrários. Trata-se de ser, sucessiva e contemporaneamente, o que manda e o que obedece e o que desobedece, ser todos, ser ninguém.

Voltando à questão do desejo, a obra de Gide que mais abertamente apresenta a questão é Corydon, com o subtítulo na versão portuguesa Tratado do homossexualismo. No prefácio desse livro, declara:

[n]ão creio de forma alguma que a última palavra da sabedoria seja o entregar-se à natureza, e libertar totalmente os instintos; mas acredito que antes de tentar contê-los e domesticá-los, é mais importante saber compreendê-los — porque inúmeras desarmonias que temos de suportar são aparentes e devidas unicamente a erros de interpretação. (Gide, 1969, p. 21)

Corydon é um ensaio socrático — trata-se de uma obra composta por quatro diálogos- que Gide escreveu com o intuito de combater os preconceitos sobre a homossexualidade e a pederastia. De alguma forma, acaba sendo uma ode à homossexualidade. Devido a um primeiro temor de enfrentar a opinião pública, seu autor só mandou imprimir secretamente em 1910 algumas cópias dos primeiros dois diálogos, 
que distribuiu apenas entre seus amigos. Entre 1917 e 1918, completou a obra, mas esta só foi publicada completamente e no seu nome em 1924. O título do texto foi inspirado no personagem homônimo de Virgílio. Corydon, na mitologia grega, é o nome de um pastor que aparece entre os poetas bucólicos (Gide, 1969).

Miller (2000-2001, p. 59), psicanalista, diz que Corydon é um extraordinário elogio da homossexualidade, no qual Gide tentava encontrar um fundamento biológico natural da condição, o que, segundo o crítico, era uma preocupação no ambiente científico da época, mas sem nenhuma importância na atualidade ${ }^{5}$.

Mesmo tenha esperado vários anos para a publicação de Corydon, Gide foi bastante corajoso ao falar da condição da homossexualidade em uma época na qual ainda era crime no mundo ocidental. Frases como "A homossexualidade, do mesmo modo que a heterossexualidade, tem degenerados viciados e doentes" (Gide, 1969, p. 38) ou "Mas se a alcova é conjugal, o vício é logo desculpado" (Gide, 1969, p. 38) fazem parte do primeiro diálogo, no qual se estabelece uma grande crítica das convenções e das regras do relacionamento tradicional homem-mulher, considerando que a sociedade que lhe correspondeu estava engolfada em um código de amor antiquado, tema que desenvolve no segundo diálogo da obra (Gide, 1969). Gide acreditava que, poucos anos depois, a discussão sobre a suposta contranatureza da homossexualidade seria superada. Nesse primeiro diálogo, escreve:

[e]stou convencido de que decorridos vinte anos, os termos: contranatureza, antinatural, etc., não poderão mais ser tomados a sérios. Apenas uma coisa admito no mundo como não sendo natural: é a obra de arte. Tudo o mais, quer por bem, quer por mal, fazem parte da natureza, e desde que não nos coloquemos na posição de

5 No momento de escrever este capítulo, encontrei um artigo no jornal web Globo.com que contraria essa afirmação de Miller. Sob o título de Genes teriam ligação com opção sexual, o artigo anuncia a descoberta de um grupo de cientistas da University of Chicago, nos Estados Unidos, de dois genes que estariam ligados à homossexualidade nos homens, o que provaria seu fundamento biológico (Genes teriam ligação com opção sexual, 14 fev. 2014). 
moralistas, é como naturalistas que convém considerá-la. (Gide, 1969, p. 38)

Paradoxalmente, o que Gide denuncia no seu Corydon é uma sociedade que constantemente estimula a heterossexualidade. "Não esqueçam que em nossa sociedade, em nossos costumes, tudo prepara um sexo ao outro; tudo ensina a heterossexualidade, tudo a convida, tudo a provoca, seja teatros, livros, jornais" (Gide, 1969, p. 45-46).

Em contraste, André Gide dedica o quarto diálogo de Corydon a enaltecer a educação da antiga Grécia, a qual se distingue particularmente pela relação entre o mestre e o discípulo. Para isso, esse diálogo acaba sendo uma exaltação do uranismo, termo que se usa para nomear a homossexualidade masculina. Gide afirma que o uranismo é responsável pela grande qualidade intelectual dos gregos e que as épocas nas quais se expandiu coincidem com uma grande exploração artística:

[...] as épocas em que se expandiu o uranismo, se assim ouso dizer, não foram, em absoluto, períodos de decadência; e não creio que seria imprudente afirmar que muito pelo contrário, as eras de grande florescimento artístico - a grega no tempo de Péricles, a romana no século de Augusto, a inglesa de Shakespeare, a italiana com o advento da Renascença, a francesa com a Renascença, depois sob Luís XIII, a persa, no tempo de Hafiz; todas foram períodos em que a pederastia mais ostensivamente - e ia dizer: mais oficialmente - se afirmava. (Gide, 1969, p. 119)

Gide também coloca como exemplo a homossexualidade masculina como grande valor da capacidade bélica dos gregos. Afirma que Plutarco faz um elogio da homossexualidade dos gregos quando indica que:

[é] preciso colocar o amante junto do amado, porque um batalhão formado de homens apaixonados uns pelos outros, seria impossível dispersá-los e derrotá-los, pois aqueles que o integram afrontariam os perigos; uns pelo compromisso afetivo em relação ao objeto de seu amor, outros por sentimento de respeito em não se deixar desonrar perante seus amantes. (citado por Gide, 1969, p. 116) 
Gide critica, então, como se veneram as obras de arte gregas como milagres de harmonia, de equilíbrio, de sabedoria e de serenidade enquanto seus costumes (está se referindo à naturalidade da prática homossexual) são deplorados pela sociedade moderna, e sua influência em todo o belo que saiu da cultura grega não é reconhecida (Gide, 1969). Quase no final do diálogo, contrastando todos seus argumentos com um tipo de educação que favorece a heterossexualidade, pergunta: "[a]credita de fato que a formação uranística das crianças da antiguidade as predispunha ao deboche, mais do que a educação heterossexual de nossas escolas modernas?" (Gide, 1969, p. 123). Finalmente, trata-se de uma queixa da hipocrisia. Em uma carta dirigida a Martim du Gard, e descrevendo seu próprio comportamento, Gide manifesta sua valorização do uranismo em 1931, depois que apareceu um panfleto anônimo que criticava os comportamentos públicos do autor.

Perverter a juventude! Como se a iniciação à volúpia, em si, fosse um ato de perversão! É exatamente o contrário! Esquece-se, ou melhor, ignora-se o que acompanha essas carícias, e a atmosfera de confiança, lealdade e nobre emulação em que nascem e se desenvolvem essas espécies de amizades! [...] Posso fazer justiça a mim mesmo: Sobre esses jovens que vieram a mim, minha influência sempre foi útil e saudável. E não há aí nenhum paradoxo: meu papel sempre foi moralizador. Sempre consegui exaltar o que havia de melhor neles! Quantos rapazes, já envolvidos com maus hábitos, eu trouxe de volta para o bom caminho, que, sem mim, teriam se abandonado a seus instintos mais vis, e se extraviado definitivamente! Quantos revoltados, preguiçosos, hipócritas, mentirosos, escutaram meus conselhos e tomaram o gosto pelo trabalho, pela honestidade, pela retidão e pela beleza! Graças, justamente, a essa atração recíproca, essa recíproca afeição... (Gide citado por Perrier, 2009, p. 18-19)

Para Gide, o comportamento homossexual é plenamente natural. De fato, assevera que a heterossexualidade deveria ser a que se considera antinatural porque, entre outros argumentos, "[o]s únicos 
comportamentos heterossexuais (dos animais), resumem-se à fecundação" (Gide, 1969, p. 79). Embora sua argumentação chegue a esse ponto de radicalidade, Corydon constitui uma prova muito relevante do que passava pela mente do autor francês, o qual falava de uma forma muito diferente na sua narrativa, na qual a homossexualidade era algo que o leitor tinha que desentranhar.

Talvez, por isso, $\mathrm{O}$ pombo torcaz tenha aparecido publicado muitos anos depois da morte de Gide. Trata-se de um conto curto no qual o autor descreve sem sombras o encontro erótico entre ele e um rapaz que ele chama de "pombo torcaz" 6 , "porque a aventura do amor o fazia arrulhar suavemente durante a noite” (Gide, 2009, p. 37). À diferença de $\mathrm{O}$ imoralista, a linguagem do narrador é muito mais direta na hora de descrever a experiência homoerótica.

Eis-nos dentro do quarto; eis-nos deitados sobre a vasta cama [...] "Isso, vamos ficar nus os dois!", exclama ele num tom alegre de criança que contrasta estranhamente com sua aparência de moça — quando começo a desvesti-lo [...] sem nenhum constrangimento e sem excessivo impudor, ele se ofereceu ao amor com um abandono, uma ternura, uma graça que eu nunca experimentara antes. Sua pele bronzeada era suave e ardente, e eu a cobri inteiramente de beijos. Num momento, ele se precipitou. Com ar divertido: "Isso! Vamos c[hupar] o p[au] um do outro" [...] Não, pensei, nem Luigi, em Roma, nem Mahommed, em Argel, possuíam ao mesmo tempo tanta graça e tanta força, o amor não conseguira extrair deles movimentos tão apaixonados e tão delicados [...] (Gide, 2009, p. 34)

Seja através das narrações sutis de $O$ imoralista, das descrições mais abertamente eróticas de $\mathrm{O}$ pombo torcaz, seja da escrita ensaística de Corydon, o que Gide me ofereceu foi um relato audaz do homossexual. Seu trabalho literário é fundamental na hora de delimitar

6 Parece que Gide tinha mesmo uma obsessão com os pombos. Em Corydon, aparece a seguinte frase: "[o]s pombos, sobretudo, parecem propensos à perversão sexual” (Gide, 1969, p. 71). 
meu imaginário sobre a homossexualidade. Além disso, constitui um testemunho que coloca na atualidade uma discussão que não se esgota. André Gide é testemunha do seu tempo e visionário de uma questão que ainda não foi resolvida. No fim das contas, um escritor corajoso que coloca sobre a mesa um assunto que muitos preferem manter oculto. Gide se inscreve, dessa maneira, em uma tradição que Sedgwick coloca entre escritores tão importantes como Oscar Wilde e Marcel Proust (contemporâneo de Gide). Segundo a crítica, o período compreendido entres esses dois últimos autores, “[...] foi muito rico quanto a tentativas de nomear, explicar e definir esta nova espécie de pessoa: o sujeito homossexual" (Sedgwick, 2003, p. 26). Eis o que retenho principalmente de Gide e de seu discurso: a sua coragem.

\section{São Sebastião e a cultura gay}

Em contraste com o discurso imoralista que se resenha na seção anterior, meu imaginário sobre a homossexualidade está também nutrido, paradoxalmente, por uma forte formação moral. Na minha educação inicial, tiveram grande importância dois tipos de leituras: os contos de fadas e as histórias dos santos. Filho de uma família com uma forte tradição católica, cresci escutando as histórias dos santos dessa religião. Os contos de fadas e as histórias dos santos não são, em essência, muito diferentes uns dos outros. Poderia dizer que ambos fazem parte da minha primeira aproximação à literatura fantástica.

Essa fascinação por essas histórias, cheias de heróis que se sacrificam por uma causa particular, também deixou uma marca profunda no meu imaginário. Finalmente, elas são fundamentais na consolidação do imaginário social do Ocidente. Falando da cultura dos santos, José María Montes (2008) assinala que, desde os primeiros séculos da era cristã, a cultura dos santos tem transcorrido de maneira paralela ao estabelecimento social e faz parte das tradições populares ocidentais.

O que as histórias dos santos têm a ver com a consolidação do meu imaginário sobre a homossexualidade? Não responderei à questão com o fato de que o amor entre pessoas do mesmo sexo seja rejeitado pela 
moral católica. Ao contrário, o que me interessa é como a cultura dos homossexuais se apropria dessas tradições. Particularmente, a cultura gay se apropria com força da imagem de um dos santos mais populares do mundo católico. Trata-se de são Sebastião.

A história de Sebastião fazia parte de um livro sobre a vida dos santos que estava na pequena biblioteca da minha infância. Mas eu só cheguei à sua imagem diretamente relacionada com o mundo gay quando me aproximei da obra de Pierre \& Gilles, o casal de artistas franceses reconhecido por sua fotografia kitsch. Eles investem na composição de imagens que se inspiram em ícones da história da arte, da cultura popular, da religião e, particularmente, da cultura gay. O santo é uma figura várias vezes retratada por eles, na qual se juntam todos os itens anteriores.

Figura 3. São Sebastião de Pierre \& Gilles. Uma das suas versões dos anos oitenta

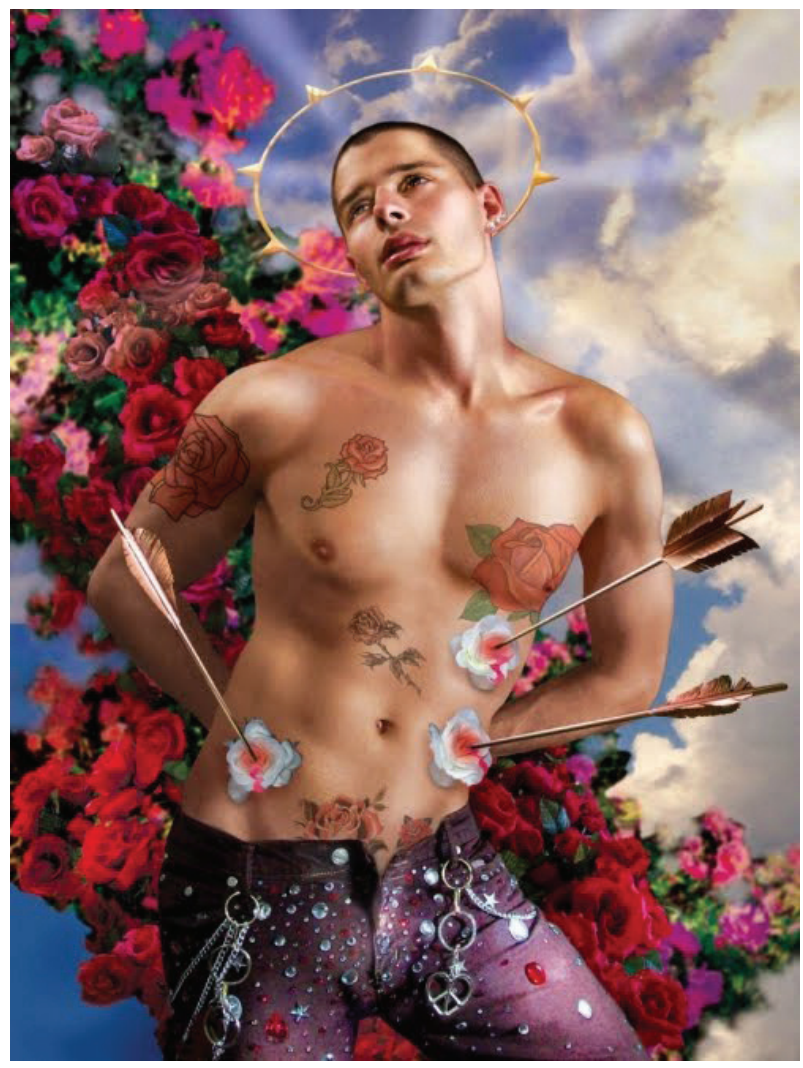


Sabe-se que são Sebastião é considerado um ícone gay há muito tempo. Isso devido à combinação do seu físico imponentemente nu (no entanto, as primeiras pinturas que se conhecem do santo o apresentavam vestido com a farda de soldado), ao simbolismo das flechas penetrando seu corpo e ao seu olhar extasiado entre o prazer e a dor, que intrigou vários artistas durante séculos.

Segundo a tradição católica (é importante assinalar que também faz parte dos santos da Igreja Ortodoxa do Oriente), são Sebastião morreu no ano 288. Foi soldado do exército pretoriano do imperador Diocleciano. Alguns autores afirmam que nasceu na região francesa de Languedoc, enquanto outros assinalam que foi em Milão ${ }^{7}$. São Ambrósio diz que fortaleceu e alentou muitos cristãos antes de serem martirizados pelos seus colegas soldados. De acordo com os relatos católicos, foi o responsável por várias conversões de altos mandatários do imperador e fez vários milagres entre as pessoas do povo. $\mathrm{O}$ maior foi o de Zoé, mulher de Nicóstrato, a qual, sendo muda, recobrou a voz depois que Sebastião fez o sinal da cruz sobre sua boca. Quando Diocleciano soube das ações do seu soldado favorito, ficou colérico e entregou Sebastião aos arqueiros, os quais o ataram a uma árvore e disparam várias flechas sobre seu corpo. No entanto, não foi assim que morreu. Irene, uma devota, resgatou-o e curou suas feridas. Em vez de fugir, Sebastião voltou a Diocleciano. Surpreso de vê-lo vivo, mandou levá-lo ao circo para ser publicamente golpeado até morrer (Montes, 2008).

Às informações fornecidas por Montes, podem ser adicionadas as de José Gros y Raguer (1961). Ele assevera que Sebastião recebeu o batismo muito novo e que era um jovem muito atraente. Filho de pais ricos e nobres, converteu Cromácio ao cristianismo, um dos principais personagens de Roma, e os irmãos Marco e Marcelino. Na época de Sebastião, a persecução contra os cristãos se concentrou entre oficiais e soldados. Sebastião avisava àqueles que eram descobertos

7 As fontes consultadas em língua espanhola (Montes, 2008; Gros, 1961) asseveram que se trata de um santo francês, enquanto as fontes de língua portuguesa (Guimarães, 2000; Chagas, 2008) assinalam a cidade italiana como seu lugar de origem. 
para que fugissem e visitava os prisioneiros. Durante seu martírio, recebeu as flechas com grande sorriso e seus olhos brilhavam com alegria "celeste" (o que parece ser uma característica comum na sua iconografia). Depois da segunda tortura, que o levou à morte, santa Lucina teve uma visão noturna, na qual o próprio mártir avisou onde estava seu corpo (para impedir seu enterro, Diocleciano jogou o corpo em uma cloaca) e onde queria que fosse enterrado. Nesse lugar, existe ainda uma igreja com seu nome. $\mathrm{Na}$ inscrição no seu sepulcro, pode se ler: "A Sebastião, mártir e campeão de Cristo, defensor da Igreja, terror da peste" (Gros y Raguer, 1961, p. 349-351).

Segundo Ariadne Guimarães e Ana Lúcia Prôa (2000), o motivo pelo qual o santo é muito reconhecido no Brasil é por ser o padroeiro do Rio de Janeiro. Sua festa é comemorada no dia 20 de janeiro. Por sua vez, Carolina Chagas (2008) inclui são Sebastião na sua lista dos cem santos mais populares do Brasil. Entre as informações históricas que ela apresenta, acrescenta a data de ingresso do santo no exército de Diocleciano: 269. Sobre sua importância na cultura brasileira, afirma:

[n]o Brasil, o culto a são Sebastião chegou com a expedição de Estácio de Sá, que em 20 de janeiro (dia da festa do santo) de 1565 fundou a cidade do Rio de Janeiro. Cultuado em toda a Europa, ele havia sido escolhido como padroeiro dos portugueses na guerra contra os franceses pela posse da Baía de Guanabara ${ }^{8}$. (Chagas, 2008, p. 201)

8 Talvez esse seja o motivo pelo qual as edições em língua portuguesa localizam a origem do santo fora do território francês. 
Figura 4. Saint Sebastien de la Guerre de Pierre \& Gilles. Obra criada pelos artistas especialmente para a mostra intitulada "Pierre \& Gilles: a apoteose do sublime", tendo como motivo o padroeiro da cidade do Rio de Janeiro (Rio de Janeiro, 2009)

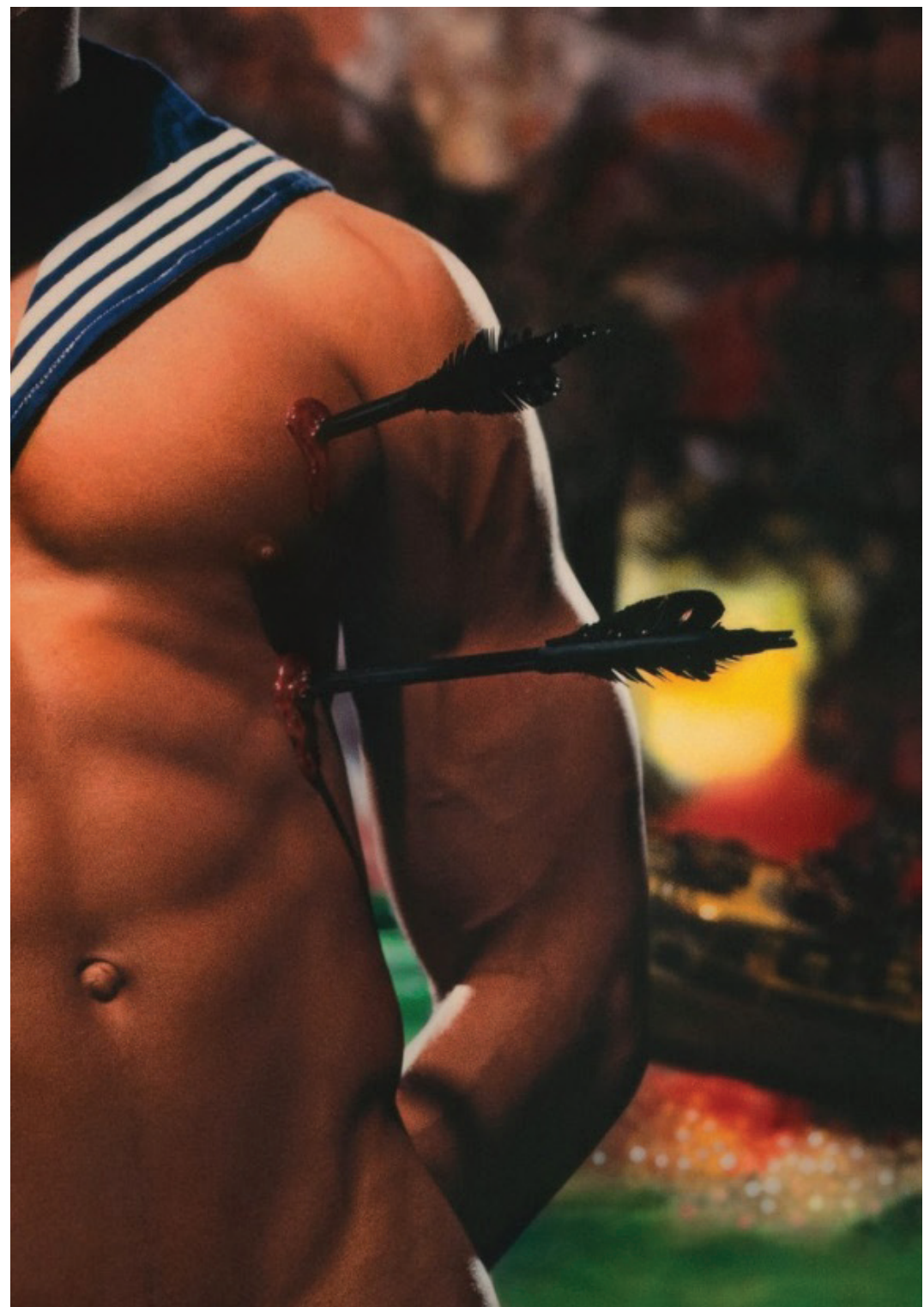


Segundo a tradição católica, as imagens e a taumaturgia são os elementos prioritários dos santos e os que mais as transcendem, já que, graças a eles, podem ser identificados ou localizados em alguma cidade ou povoado (Montes, 2008). Por isso, não é estranho que a imagem do santo seja tão diretamente associada à cidade do Rio e à sua cultura popular. Mostra disso são as constantes referências à imagem do santo na música popular que toma ao Rio de Janeiro como tema central, como Estação derradeira, de Cida Moreira (com seu "São Sebastião crivado") e Sebastian, de Gilberto Gil e Milton Nascimento.

Sebastian, Sebastião

Diante de tua imagem

Tão castigada e tão bela

penso na tua cidade

Peço que olhes por ela.

Cada parte do teu corpo

Cada flecha envenenada

Flechada por pura inveja

é um pedaço de bairro

é uma praça do Rio

Enchendo de horror quem passa.

Oô cidade, ô̂ menino

Que me ardem de paixão

Eu prefiro que essas flechas

Saltem pra minha canção

Livrem de dor meus amados.

Que na cidade tranquila

Sarada cada ferida

Tudo se transforme em vida

Canteiro cheio de flores

pra que só chorem, querido,

Tu e a cidade, de amores. 
Como todos os santos, a Sebastião se adjudicam várias causas. É padroeiro dos armeiros, besteiros, curtidores, oleiros, comerciantes de ferro, pedreiros, jardineiros e vendedores de escovas; protetor das mulheres, dos soldados, dos moribundos, das feridas e dos poços (Montes, 2008). É invocado contra todo tipo de epidemias, contra a peste e é padroeiro dos alfaiates (Chagas, 2008). Surpreende, tratando-se de uma publicação católica, que Carolina Chagas reconheça a importância do santo na cultura homossexual. Sobre isso, assinala: "[a] comunidade gay tem grande simpatia pelo santo e o considera protetor” (Chagas, 2008, p. 201).

Segundo Miguel Arroyo Fernández (2011), é muito significativo que a figura do santo ferido a flechaços e moribundo se transformasse a partir da Renascença na figura homoerótica por excelência, até o ponto de ter permanecido, no século XX, como um ícone gay. B. Parker (citado por Arroyo-Fernández, 2011) mostra que o santo se converte em um jovem belo, cujo corpo nu inflama a sensualidade de quem o contempla. As flechas, segundo o pesquisador norte-americano, parecem representar mais o amor de Cupido do que a morte e a agonia de Sebastião, elas denotam mais êxtase e prazer do que dor.

Por sua vez, R. Kaye (citado por Arroyo-Fernández, 2011) diz que alguns relacionam a figura do santo com a suposta natureza sadomasoquista dos homossexuais, enquanto outros veem nele o reflexo do martírio que sofre o homossexual em uma sociedade que nega a legitimidade da sua experiência ou uma amostra de como os gays se entregam ao sofrimento ou ao suicídio. 
Figura 5. São Sebastião (1617-1619) de Guido Reni

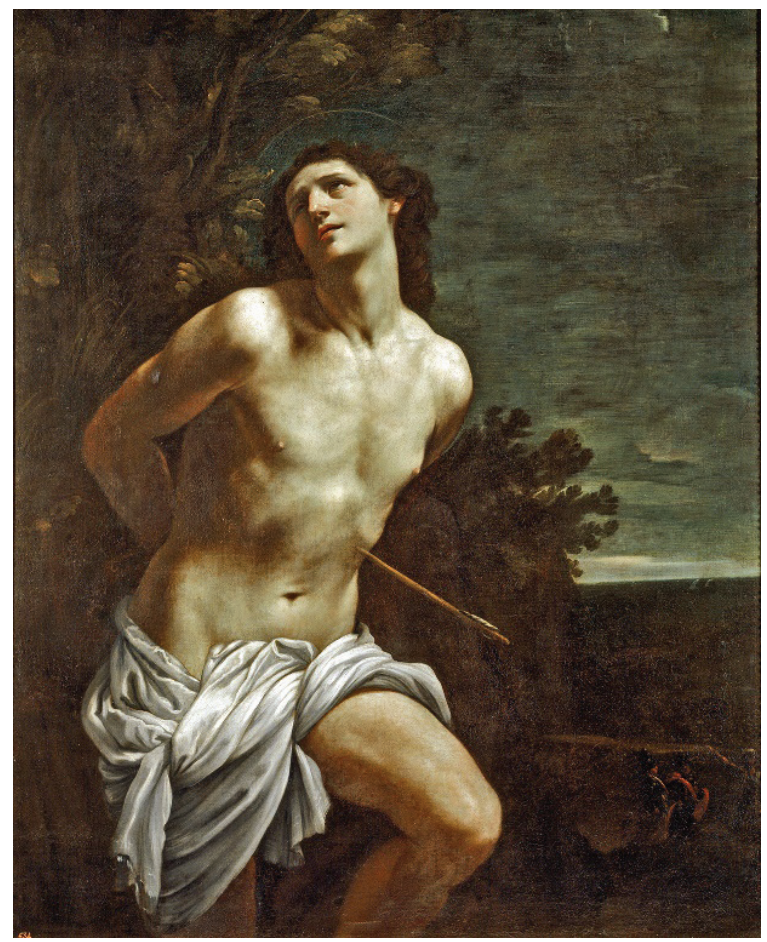

A figura de são Sebastião tem sido motivo de inspiração de grandes artistas (já foi mencionado o exemplo dos fotógrafos Pierre \& Gilles). Arroyo Fernández (2011) cita vários exemplos com figuras tão importantes como a dos cineastas Derek Jarman e Paul Humfress no filme Sebastiane (1976) e os escritores Federico García Lorca (conservam-se vários desenhos feitos por ele sobre são Sebastião e detectam-se várias referências ao santo na sua poesia juvenil e na sua peça teatral El público), Yokio Mishima (que expressou sua fascinação pelo São Sebastião de Guido Reni (Figura 5) e se fez fotografar várias vezes adotando as poses do mártir, a última poucos dias antes de se fazer o haraquiri) e Tennessee Williams (que, na peça intitulada Suddenly, Last Summer, dá o nome de Sebastian ao seu protagonista homossexual).

A primeira notícia que se tem de são Sebastião como uma representação artística foi em um mosaico na basílica de Saint Apollinaire Nuovo, em Rávena, Itália, entre 527 e 565. Outra das primeiras representações é um mosaico na Igreja de São Pietro, em 
Vincoli, Roma, que pertence provavelmente ao ano 682. Até aí, as representações do santo o mostram como um adulto elegantemente vestido.

Em um interessante blog que apresenta um estudo semiótico bem-selecionado da iconografia do santo desde 527 até o presente, Fredrick W. Bunce (2011) assinala que uma das primeiras representações conhecidas do santo seminu foi encontrada em 1435. A partir daí e da Renascença, continua sendo apresentado como um jovem seminu. Nessa época, começou a aparecer em gravuras e pinturas de artistas como Botticelli, Andrea Mantegna, Guido Reni, Giuseppe Cesari, Giovanni Bazzi $^{9}$ (Figura 6), Tintoreto, Tiziano, Girgione, Perugino e El Greco, entre outros (Ryanoceros, 2007).

Figura 6. São Sebastião (1525) de Giovanni Bazzi (“Il Sodoma”)

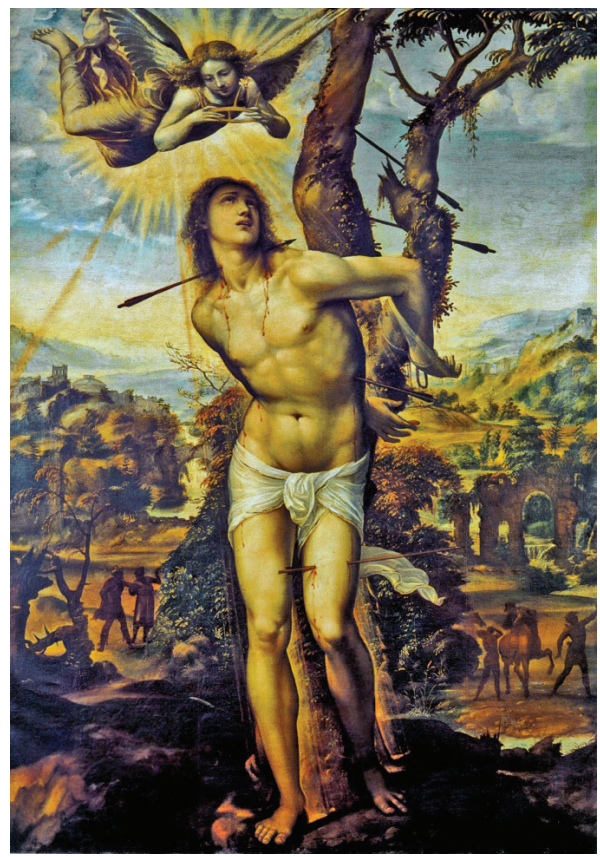

9 Bazzi assinava suas obras como "Sodoma". Relata-se que era chamado de "sodomita”, não só pela sua assinatura, mas também pelo seu costume de confraternizar com jovens adolescentes. Essa história acabou sendo narrada no espetáculo unipessoal produto desta pesquisa. 
Nos séculos seguintes, são Sebastião continuou sendo muito apreciado pelos artistas que viram nele um ícone da beleza masculina. No século XIX, destacam-se as referências de Oscar Wilde, outro admirador da pintura de Reni (Figura 5), ao santo. Depois de sair da prisão, pelo crime de pederastia, o escritor usou o pseudônimo de "Sebastian Melmoth" e visitou a tumba do santo (Ryanoceros, 2007).

Já, no século XX, pintores, fotógrafos, escultores, escritores e muitos outros artistas usaram o santo como ponto de partida para suas criações. Das obras mais contemporâneas que tiveram repercussão na consolidação da minha imagem do santo, a que mais influência causou foi a versão do pintor mexicano Ángel Zárraga (Figura 7). De todas as imagens que tinha consultado, a única que dá uma participação destacada à figura da mulher é a versão de Zárraga. Isso me produziu uma grande comoção. Quando vi a obra, imediatamente relacionei a imagem ao tipo de relação que é descrita por André Gide em $O$ imoralista do protagonista (Michel) com sua esposa (Marceline).

Figura 7. Ex voto, Martirio de San Sebastián (1912) de Ángel Zárraga

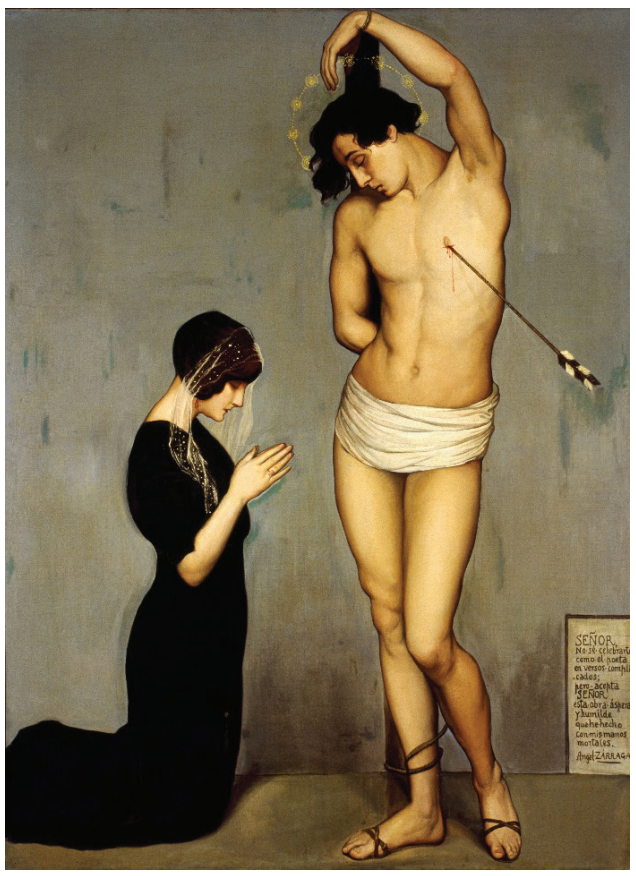


O Ex voto, de Zárraga, é uma pintura que mistura belamente o agradecimento místico ${ }^{10}$ (de fato, a expressão ex voto se refere a uma ação de agradecimento a um santo) e a carnalidade profana. Nela, pode se apreciar a sensualidade do corpo masculino em contraste com a atitude piedosa da devota que fica de joelhos do lado do santo. Mais do que um ato de agradecimento, a pintura é uma provocação. Muito da narração apresentada no espetáculo unipessoal foi fruto das suscitações dessa pintura.

Nas últimas décadas, a força de são Sebastião como ícone gay tem adquirido mais acepções. Para muitos, a figura do santo é uma metáfora da "saída do armário", sendo um santo torturado por revelar à instituição pública seu verdadeiro amor. Além disso, é uma bandeira contra o crime da homofobia, comparando o santo com vários homens que têm sido torturados e assassinados por sua condição homossexual. Finalmente, sendo ele padroeiro das epidemias, sua imagem também acabou sendo associada ao vírus da imunodeficiência humana (HIV), doença que, no começo, se pensou exclusiva dos homossexuais. O trabalho do pintor neoexpressionista Julian Schnabel (Figura 8), por exemplo, é um dos que parte da imagem do santo para falar da epidemia.

$10 \mathrm{Na}$ parte inferior direita da obra, pode se ler o que seria em português: "SENHOR: não sei te celebrar como o poeta em versos complicados; mas aceita, SENHOR, esta obra áspera e humilde que fiz com minhas mãos mortais" (tradução minha). 
Figura 8. Saint Sebastian (1979) de Julian Schnabel

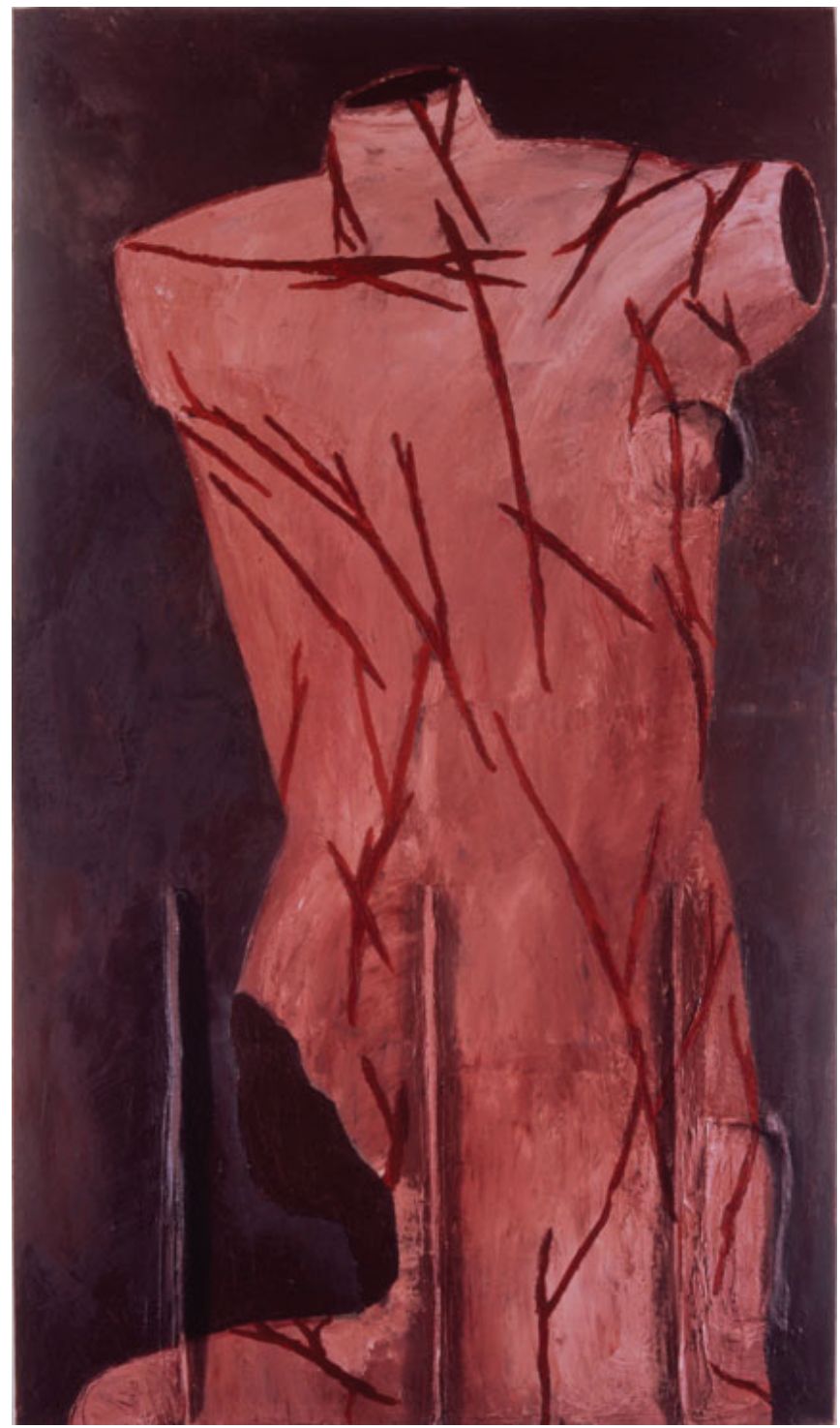

No entanto, não foram usadas as versões mais contemporâneas como materiais no processo criativo do espetáculo unipessoal. Ao contrário, foi a imagem clássica do santo penetrado pelas flechas com paradoxal gesto de prazer que fazia parte mais contundentemente do meu imaginário sobre a homossexualidade. Também eram essas imagens que me remetiam à ideia de beleza masculina que tanto se 
divulga em alguns setores do mundo gay e que está relacionada com a paixão pederasta da qual falava Gide. Um grande exemplo desse conceito aparece no São Sebastião de Agnolo Bronzino (Figura 9). Assim como a pintura de Zárraga foi associada no meu imaginário com a narração de $O$ imoralista, a de Bronzino me deu uma fisicalidade para o adolescente protagonista do encontro erótico de $\mathrm{O}$ pombo torcaz (Ferdinand).

Figura 9. São Sebastião (1525-1528) de Agnolo Bronzino

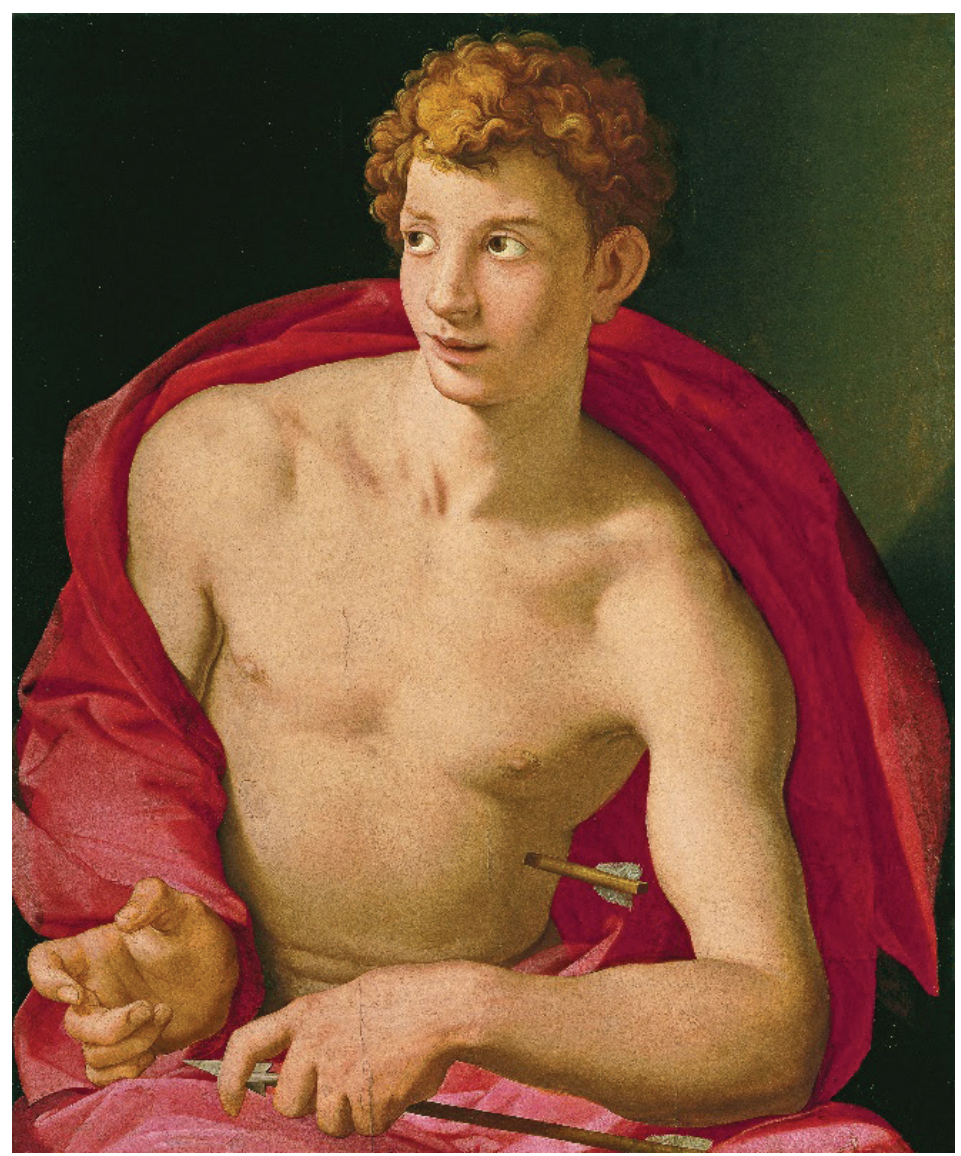

Note-se o contraste entre a flecha que penetra o corpo do jovem e a expressão de serenidade, quase alegria, do seu rosto. O Sebastião de Bronzino representa esse ideal de beleza masculina do jovem atleta que, mesmo sendo torturado, sorri diante da adversidade. 
Segundo Bunce (2011), a representação física de são Sebastião variou consideravelmente pelos séculos: tem sido representado como jovem adulto, adolescente ou velho; em todas as posições possíveis (deitado, amarrado de diversas formas, sentado, de joelhos etc.); em agonia e em êxtase; vivo e morto; másculo ou andrógino; sozinho ou na companhia de outras personagens ou de outros santos (como são Lorenzo e santa Irene de Ávila, entre outros).

A diversidade da paisagem iconográfica do santo fez com que a pesquisa me levasse até inúmeras representações pictóricas. As apresentadas aqui são só uma pequena porcentagem das que me acompanharam no processo criativo. Além das suas imagens, as histórias narradas sobre ele e, inclusive, sua oração se converteram em alguns dos materiais principais da encenação de Meus caros amigos.

Glorioso mártir são Sebastião, soldado de Cristo e exemplo de cristão. Hoje nós viemos pedir vossa intercessão junto ao trono do senhor Jesus, nosso salvador, por quem destes a vida. Vós que vivestes a fé e perseverastes até o fim, pedi a Jesus por nós para que nós sejamos testemunhas do amor de Deus. Vós que esperastes com firmeza nas palavras de Jesus, pedi a ele por nós para que aumente nossa esperança na ressurreição. Vós que vivestes a caridade para com os irmãos, pedi a Jesus para que aumente nosso amor para com todos. Enfim, glorioso mártir são Sebastião, protege-nos contra a peste, a fome e a guerra; defendei nossas plantações e nossos rebanhos que são dons de Deus para o nosso bem, para o bem de todos. E defendeinos do pecado que é o maior mal, causador de todos os outros. Assim seja. (Chagas, 2008, p. 200)

Tendo como materiais o literário fornecido por André Gide e o iconográfico fornecido pela imagem de são Sebastião, só falta adentrar na experiência autobiográfica, como se descreve na continuação. 


\section{A experiência autobiográfica}

As leituras e a experiência iconográfica não são muito diferentes de qualquer outro tipo de vivências na consolidação do imaginário. De fato, fazem parte do que posso denominar como experiência pessoal. Finalmente, toda experiência (a leitura de uma obra literária, a visita a um museu, a participação em um show musical ou simplesmente uma conversa com amigos) passa de ser um acontecimento social a ser uma referência que fica no imaginário como apropriação pessoal de alguma ideia. Quando falo aqui da experiência autobiográfica, devo esclarecer que todo o anterior faz parte dela. Só que, nesta parte do capítulo, falarei desse assunto como aquilo que não está associado com a relação particular com uma obra criada ou um documento produzido por um ente externo, enfim, tudo aquilo que não estaria relacionado com a apropriação pessoal de uma obra produzida por outro. Trata-se de um esforço metodológico de classificar os materiais criativos ciente de que seria uma delimitação rígida, mas com o propósito deliberado de não cair na generalização pouco produtiva de que tudo é subjetividade.

Etimologicamente, a palavra autobiografia é um neologismo culto aparecido na Inglaterra (autobiography) ao redor do ano 1800. A palavra é construída a partir da união de três lexemas de origem grega: autós (si mesmo), bios (vida) e graphé (escrita). Assim, autobiografia significa autoescrita da própria vida (Puertas, 2004). L. Scarano (citado por Puertas, 2004) define o autobiográfico como o trânsito de um passado (bios) à ordem dos signos (graphé) para configurar um sujeito (autos) a partir de si mesmo ${ }^{11}$. Essa última definição resulta muito adequada para esta pesquisa e para o processo criativo do espetáculo unipessoal que queria atingir. De fato, a experiência pessoal

11 São muitos os termos que o conceito de autobiografia tem adquirido depois da publicação das Confissões de Jean-Jacques Rousseau em 1782. Alguns deles, citados por Jesús Camarero (2011, p. 11), são: confissão, egotismo, conexão de uma vida, gnose do eu, autobiografema, pacto autobiográfico, autobiotexto, egologia, autografia, escritura de si mesmo, escrituras do eu, autoficção, autorreflexão, linhas de vida, signos de vida, autoconsciência, autognose, ontogênese ou ontopráxis, entre outros. 
é considerada aqui o ponto de partida para a configuração do sujeito criador; nesse caso, o ator.

Segundo Marcia Abujamra (2013),

[o] uso da autobiografia no teatro tem relação íntima com o que Michael Kirby chama de autoperformance que, segundo o ensaísta, é um trabalho criado e interpretado pela mesma pessoa a partir de um material pessoal, que normalmente assume a forma de um monólogo, mas nem sempre e não necessariamente (p. 78)

Essas ponderações têm muito a ver com a proposta desta pesquisa e encontram, nas palavras da pesquisadora e do teórico citado por ela, coincidências na hora de considerar o material criativo na experiência autobiográfica. Assim, vivências do meu passado podem se tornar materiais apropriados para a criação de uma obra que pretende partir de mim mesmo. O autobiográfico, nessa ordem de ideias, seria material fundamental e teria dois sentidos: um argumental e outro político.

No primeiro sentido, tentaria resgatar as lembranças do passado para encontrar possíveis histórias ou momentos que tenham algum tipo de relevância na formação da minha experiência como homossexual. Esses materiais narrativos contribuiriam momentos para a construção de uma ficção que posteriormente seria entregue ao público. Partindo disso, como determinar quais seriam essas experiências relevantes na ação criadora?

Para iniciar essa busca dos elementos do meu passado que se converteriam em materiais para a construção do espetáculo, a retrospecção e a memória seriam minhas ferramentas. Puertas (2004) assinala que o olhar retrospectivo é uma das características estruturais do autobiográfico, já que só por meio do passado, da busca das origens, é possível interiorizar e compreender a raiz íntima dos comportamentos e da forma de ser que se procuram.

O exercício retrospectivo não podia se representar simplesmente em um estado de concentração, uma vez que a garantia de que as lembranças chegassem como por uma espécie de indução hipnótica era escassa. Embora saiba que, para o acesso ao passado ser possível, a memória é 
elemento fundamental. Como capacidade intelectual, ela tem uma função estrutural na reconstrução do eu e na atualização do passado (Puertas, 2004). Mas como estimulá-la se, como assinala Guillermo Cabrera Infante (citado por Barchino, 2013), ela é uma tradutora simultânea que interpreta as lembranças de maneira arbitrária e quem acredita que pode manipulá-la é quem depende mais dessa arbitrariedade?

A resposta foi dada pelos materiais anteriormente descritos. $\mathrm{O}$ material de trabalho não se reduz às lembranças das minhas leituras e das pinturas que tanto me inquietavam, mas elas mesmas, como documentos físicos, que me acompanhavam na sala de ensaio. Dessa forma, minhas lembranças teriam que estar fisicamente ao meu alcance. Esse imperativo nasceu da crença que como artista sempre tive de que em arte tudo se traduz em experiência física, o que coincide com o que Luigi Pareyson qualifica como a necessidade de extrinsecação física na arte. "A arte é necessariamente extrinsecação, porque só e precisamente por este seu carácter físico e sensível ela se especifica, distinguindo-se da artisticidade genérica que é inerente a toda a vida espiritual" (Pareyson, 1997, p. 153).

Assim, fotografias, objetos associados a experiências importantes do passado, documentos escritos (como cartas e e-mails), músicas que me tocaram em um momento particular da vida e até um computador com acesso às minhas contas nas redes sociais iam e saiam da sala de ensaio em momentos específicos da etapa criativa. Nesses elementos, procurava objetivar aquilo que é tão volátil e dificilmente manipulável como a memória. Encontrava neles vestígios ${ }^{12}$ do passado, constituíamse objetos que traziam mais tangivelmente as imagens que estava procurando.

O sentido de considerar esses objetos como materiais de trabalho —e não as lembranças ou as experiências do passado a que eles

12 Iván Izquierdo (2013), que tem dedicado toda sua vida ao estudo da memória, assinala que "[1]embramos através de vestígios, e sobre vestígios reconstruímos cada vez e cada vez reconstruímos coisas diferentes" (p. 19). Sobre o trabalho do artista, afirma: "[u]ma coisa maravilhosa da arte do ator, da arte do executante do instrumento, da arte do cantor é que com vestígios ele constrói, reconstrói obras-primas” (Izquierdo, 2013, p. 18). 
remetem- é validado, de novo, por Pareyson (1997), que afirma que "[s]ão matéria da arte os materiais físicos de que se servem os artistas, vistos na sua constituição natural, no seu uso comum e na sua destinação artística" (p. 159, itálico meu). Mas também não se pretende desconhecer aquela carga espiritual dos objetos. Como assinala Pareyson (1997),

[u]ma explicação da arte está ligada à possibilidade de mostrar como nela, figuração interior e operação executiva, atividade espiritual e extrinsecação física, idealidade e sensibilidade, longe de se contraporem ou de se sucederem, ou de se anularem uma na outra, coincidem, pelo contrário, sem resíduo. (p. 152)

Voltando ao assunto da memória, já que ela faz parte fundamental da conformação do imaginário, o que aqui ganha uma importância capital, essa aproximação ao passado acabou sendo mais uma apropriação pessoal da experiência social. Por isso, a discussão sobre a origem social ou pessoal da memória continua vigente.

Abandonar-se à criação de uma identidade específica é a tarefa que se assume em todo escrito autobiográfico, já que se utiliza a memória como eixo condutor que articula e estrutura o discurso dessa busca, inscrita, ao mesmo tempo, no limite de umas relações sociais e de uma comunidade cultural. Não deve se esquecer, no entanto, que a memória tem o mencionado componente coletivo e social enquanto se baseia na fragilidade do indivíduo aferrado a sua própria continuidade temporal graças à lembrança do que foi, para se entender melhor a si mesmo. (Puertas, 2004, p. 27, tradução minha)

Nesse caminho, minhas lembranças foram usadas como materiais no intuito de serem reinterpretações do meu passado que se acoplaram diretamente com os outros elementos selecionados (leituras e imagens) na construção de uma ficção própria.

Mas não eram só os eventos do passado o que me interessava como material autobiográfico. O outro sentido anunciado de acessar a esses 
materiais é político. Maria Cristina Nunes Ferreira Neto (2005) assevera que "[...] os textos autobiográficos e biográficos estão interligados com os interesses, os projetos, os desejos, a intenção e as inquietações vividas pelos seus autores" (p. 1536). Isso converge com os propósitos desta pesquisa, ou seja, a criação de uma encenação que permitisse apresentar minha visão do mundo ao redor de uma inquietação que me envolve e me preocupa como sujeito: a falsa moral que cerca a experiência homossexual ainda nos nossos dias.

Para isso, não poderia ignorar minha própria condição gay, além de artista interessado em debater a questão no contexto do palco. Em concordância com o assinalado por Nunes, essa inquietação pessoal ineludivelmente implica o uso do autobiográfico. Assim, não só usaria minhas vivências, mas também a obrigação de falar com nome próprio, como sujeito que vive, padece e tem algo para dizer sobre a questão que lhe causa tanta inquietação.

Assumir esse "eu" na cena, independentemente da construção de uma ficção que nunca teve a intenção de se converter em um ato confessional ou entrar na estética do que seria um teatro autobiográfico —a experiência pessoal é um material a mais—, já determinou esse sentido político que implica a necessidade de expor o tema. $\mathrm{O}$ "eu” que estaria assumindo é o eu-sujeito-homossexual. A revelação no palco dessa identidade guarda uma estreita relação com as estruturas de ocultamento e revelação já mencionadas anteriormente, as quais “[s]ão estruturas dotadas de uma incoerência assaz criativa, embora perigosa, que se vêm, entretanto, condensando de forma contínua e opressiva em certas figurações da homossexualidade" (Sedgwick, 2003, p. 11).

É nesse sentido que o falar em nome próprio se torna um ato político. Para atingir esse propósito, se, no primeiro capítulo deste livro, faço valer meu direito ao no man's land de Jean-François Lyotard (1996), neste segundo capítulo, faço questão de reivindicar meu direito ao uso da primeira pessoa do singular.

Matías Barchino reflete sobre esse assunto em um ensaio que trata o tema em relação com os escritores hispano-americanos. Ele adverte, a partir das ponderações do escritor argentino Julio Cortázar, que os narradores de tradição hispânica sentem algum tipo de receio na hora de tratar sobre si mesmos, já que temem ser tidos por vaidosos e que 
a expressão do eu precisa ser devidamente explicada e justificada nas suas obras porque o fato de usar a própria vida como material criativo é recebido como uma insolência, o que não parece preocupar outro tipo de tradições, como a europeia (Barchino, 2013).

Por sua vez, no contexto das artes cênicas, torna-se relevante ver como o uso de material autobiográfico tem ganhado importância nos últimos anos dentro do continente. Um exemplo disso aparece no artigo de Paula Fernández (2008), O biográfico no teatro portenho, no qual a pesquisadora assevera que "[n]os últimos anos multiplicaram-se as obras que usam o biográfico, o registro documental e o autobiográfico como material suporte da ficção teatral na cena argentina” (p. 1). Note-se como a autora dá o status de material à experiência biográfica, o que coincide com o apresentado neste capítulo.

No caso do trabalho do ator, parece que o preconceito do qual são vítimas os escritores hispano-americanos é o mesmo, dado que a mestria do artista cênico é comumente avaliada pela capacidade de interpretar os outros. Sobre isso, Martha Ribeiro apresenta uma discussão semelhante quando fala de teatro autobiográfico, desta vez, para se referir à questão da ficção.

Juntar os dois termos, autobiografia e obra teatral, parece, à primeira vista, um paradoxo, pois teatro é a arte da ficção e autobiografia é, como simplifica Lejeune, a biografia de uma pessoa real feita por ela mesma. $\mathrm{O}$ teatro fala através de personagens ficcionais e a autobiografia possui como condição imediata uma identidade entre o narrador e o herói da narração. Por esta reflexão, podemos dizer de imediato que um teatro autobiográfico para existir não pode prescindir da presença em cena do autor. (Ribeiro, 2006, p. 39)

Fazer uso da primeira pessoa do singular, no caso desta pesquisa, implica uma atitude emancipada que quebra algumas das práticas mais tradicionais (o que não quer dizer que seja novidade) e, nessa ordem de ideias, se assume como uma postura política.

O uso gramatical da primeira pessoa é habitual na construção autobiográfica porque, como assinala B. Ciplijauskaité (citado por 
Puertas, 2004), a narração em primeira pessoa parece particularmente apropriada para conseguir a impressão de uma estrutura viva e, no caso da literatura, é mais verossímil do que a terceira. Isso não quer dizer que não se usem outras formas gramaticais ou que a utilização da segunda ou terceira pessoa (singular ou plural) traia o princípio autobiográfico. Essa característica habitual do autobiográfico é bemacolhida para os interesses do espetáculo unipessoal, o qual coincide em usá-la com frequência no discurso verbal.

A utilização da primeira pessoa do singular (lembro aqui as palavras de Ferracini, que vê no espetáculo unipessoal a possibilidade de coletivizar uma singularidade) favorece o falar com nome próprio. De fato, seu uso na consolidação do espetáculo unipessoal que saiu desta pesquisa fez com que o público não distinguisse a ficção da biografia na recepção da peça ${ }^{13}$.

Voltando à questão de falar com nome próprio, para nossos interesses, essa é outra caraterística do autobiográfico que esta pesquisa acolhe. Segundo P. J. Eakin, o nome próprio é o tema profundo da autobiografia e, segundo Ph. Lejeune, garantia da unidade da nossa multiplicidade (citado por Puertas 2004).

Singularidade e multiplicidade, temas que serão abordados no terceiro capítulo, serão princípios criativos fundamentais nesta pesquisa. Por enquanto, e só falando do primeiro, é importante sublinhar que, no fundo de toda criação, subjaz a experiência pessoal, e que o uso do eu representa um campo perfeito para a experimentação artística (Barchino, 2013). Como diria a Nobel chilena Gabriela Mistral, toda obra é autobiográfica, mas não do jeito que todo mundo acha.

O discurso autobiográfico faz possível a aparição da singularidade precisamente porque, como assinala Jesús Camarero (2011), reconfigura e oferece uma possibilidade de linguagem para o processo de identidade do seu autor por meio da criação discursiva. Devido a essa configuração da identidade, o autobiográfico está intimamente ligado à reflexibilidade. Segundo Camarero (2011), a reflexibilidade

13 O uso da primeira pessoa como metodologia do trabalho criativo e da impressão de autobiografia que se deu durante a recepção do espetáculo será objeto dos capítulos terceiro e quarto. 
é um fenômeno que consiste na capacidade da obra de arte de se referir a si mesma, de se dirigir ao seu próprio processo de produção e de criação, de tal maneira que tudo isso faz parte da obra final sem prejuízo do que quer narrar ou apresentar.

Finalmente, o projeto autobiográfico se sustenta na soma de um desejo de verdade e da busca de uma linguagem particular (Camarero, 2011), consonante com os interesses do meu propósito de criar um espetáculo unipessoal no qual meu eu ator venha alcançar a categoria de autor da obra para que o palco seja esse lugar onde minha singularidade possa ser compartilhada. 
